\title{
Meat production from wild herbivores
}

\author{
By R. N. B. Kay, Rowett Research Institute, Bucksburn, Aberdeen AB2 $9 S B$
}

Wild herbivores have rather suddenly become the object of much interest. Their potential for meat production has been convincingly argued (Darling, rg6oa; Talbot, Payne, Ledger, Verdcourt \& Talbot, I965; Maloiy, 1965; Ledger, Sachs \& Smith, 1967; Crawford, 1968a). The International Biological Programme has espoused their cause, as Phillipson (1967) has described to us, and has published a guide to the study of their productivity (Golley \& Buechner, I968). They can be exploited for meat production at various levels of intensity, ranging from hunting or game-cropping to more intensive husbandry of captive animals and complete domestication. These various systems will be considered below, but first one should ask why we should attempt to make use of wild animals at all.

\section{Why eat wild animals?}

The easiest way to produce more meat is undoubtedly to exploit conventional farm animals more widely and more intensively. Unfortunately, increased production of meat by the rich countries of the world does little to improve the nutrition of the poor; the need is not simply to produce more meat but to produce it in the right place. Shortage of animal protein tends to occur, of course, in regions which lack the capital and experience needed to found an intensive animal industry, and which often also have a climate or terrain unsuited to our present domestic animals. In such countries it may be realistic to make better use of the indigenous wild herbivores.

Exploitation of difficult habitats. The persuasive ecological arguments for making use of wild herbivores for meat production in areas which cannot be managed intensively are, thanks to authors such as Darling ( $1960 a$ ), well known. The point is made succinctly by Harthoorn (1968): 'Where man has domesticated animals he has undertaken to provide an environment most suitable for their reproduction and production ... Where we cannot alter the environment in any significant way, the animals that are accustomed to the environment may be the most suitable animals to use the land'.

About $30 \%$ of the land surface of the world is too arid for intensive development (Price \& Springfield, I952); other large areas are mountainous or support only tundra or taiga vegetation. In the more favourable areas, complex communities of plants have evolved which often attain quite as high a primary productivity, in terms of trapping solar energy, as farm crops. A richly varied population of herbivores makes full use of the vegetation available, different species grazing it in succession through the seasons and at all levels from the tree tops to the ground (see, for example, Martin, Zim \& Nelson, I95I; Darling, I960a,b; Vesey-Fitzgerald, I960; Lamprey, 1963 ). Talbot ( 1963 ) estimates that East African acacia savannah and bushland is able to carry roughly a five times greater biomass of wild ungulates than of 
domestic animals. Moreover, the restricted feeding habits of the domestic species may make poor use of the vegetation and at the same time cause the range to deteriorate. From remote historical times up to the present day, clumsy attempts to introduce domestic species of plants or animals into marginally arid regions have led to catastrophic collapse of the ecosystem and the appearance of dust-bowls and deserts.

Adaptations of wild herbivores. Although wild herbivores show numerous adaptations of anatomy, physiology and behaviour which suit them to the ecosystem in which they are found, native animals have often been ousted by introduced species (Ziswiler, 1967 ). Versatility is often of greater value than precise adaptation especially when human activity may change the habitat. Even so, there are many examples of the superiority of native herbivores over introduced domestic species. The behaviour and physiology of many African herbivores enable them to thrive in a hot, dry climate where efficient water economy is essential; the camel (Schmidt-Nielsen, 1964) and the eland (Taylor \& Lyman, 1967) are particularly well documented in this respect.

In some habitats there is no question of using domestic species. Waterless parts of the Sahara where even the camel cannot survive used to be grazed by herds of addax, though now this remarkably interesting beast is in danger of extinction (Fisher, Simon \& Vincent, 1969). The lichen woods and heaths of Labrador, which are almost barren at present, might support 500000 reindeer capable, with careful management, of an annual increment of $40 \%$ (Hustich, I95I). In some tropical regions the plants growing in rivers, lakes and estuaries are eaten by the manatee and dugong. These aquatic mammals are still hunted for their meat and oil, though their numbers are dangerously diminished (Fisher et al. 1969), and Bertram \& Bertram (I968) have urged that they should be encouraged both for weed clearance and meat production.

Endemic disease may also rule out the introduction of exotic domestic species. Trypanosomiasis and swine fever are the scourges of cattle and pigs over large tracts of Africa, though the diseases scarcely affect native ungulates.

Digestive efficiency. There is little evidence to suggest that wild herbivores are able to make better use of the food they consume than would domestic animals. Only a few controlled digestibility trials have been made. Reindeer have been found to digest roughages at least as well as cattle and sheep (Nordfeldt, Cagell \& Nordkvist, 196r; Eriksson \& Schmekel, r962) while the red kangaroo (Foot \& Romberg, r965) and red deer (Maloiy, Kay, Goodall \& Topps, 1970) manage a little less well than sheep. Probably the fermentation process is much the same in all animals that ferment food in their stomachs, the extent of digestion depending mainly on how long food is retained in the fermentation chamber. The most important differences between species relating to nutrition seem to be behavioural-appetite and choice of diet-rather than digestive. Even so, there are some curious species differences in tolerance to plant toxins and essentials oils (Pirie, 1968).

Carcass quality. The quality of the carcasses of wild ungulates, and the killing-out percentage, is generally quite as good as that of domestic species (Talbot et al. 1965 ; Ledger et al. 1967; Ledger, 1968). African ungulates are characteristically very lean; 
the carcasses rarely contain more than $2.5 \%$ of fat, a small fraction of that contained by domestic ruminants. Wild ungulates from temperate regions tend to show greater seasonal fluctuations in body-weight and fat content (Wood \& Cowan, I968). Crawford (1968b) has suggested that the scarcity of depot fat in wild African ungulates may, in view of the possible association between the intake of saturated fatty acids and atherosclerosis in man, be an argument favouring meat production from such animals, though Garton ( 1969 ) has questioned this opinion. It would be interesting to discover how far the lack of depot fat in these wild animals is a characteristic of the species and how far it simply reflects their diet. The aminoacid composition of lean meat varies very little between species (Crawford, I9686) and wild ungulates, when properly butchered and prepared, provide perfectly acceptable meat (Talbot et al., 1965).

\section{Management systems}

Crops of wild animals may be taken quite empirically, by hunting, or with the deliberate purpose of maximizing sustained production, by game-cropping. Alternatively, using suitable species, captive animals may be managed extensively or intensively. Such husbandry, through either unintended selective pressures or deliberate breeding policy, leads to alteration of the genotype of the animal and gradual domestication.

Hunting. Man has always been a hunter and much of our knowledge of palaeolithic man is centred on his hunting technology. In their introduction to the International Union for Conservation of Nature and Natural Resources 'Red Book' Fisher et al. ( 1969 ) consider the impact of man upon the magnificent climax of Pleistocene mammals. In both primitive and modern communities, hunting is often governed by rules and taboos which tend to prevent the destruction of the species hunted. Such pragmatic controls failed whenever there was an advance in hunting technique or a migration of relatively advanced people. The rate of extinction of animals has accelerated greatly wherever man has penetrated, notably in Europe during the past 100000 years and in North America during the past 20000 years. The Polynesians who colonized New Zealand 1000 years ago extinguished about thirty-six species of birds in the 800 years before Europeans appeared.

Today, however, it is not so much hunting as destruction or disturbance of the habitat, together with introduction of new predators or competitors, which threatens species with premature extinction (Ziswiler, 1967 ). The intelligent hunter need be no enemy of the conservationist, and hunting may still yield useful quantities of meat. Slaughter of kangaroos in Australia, though practised inefficiently in terms of meat production, provided about 2000 tons of meat for export in 1960-6I (see Ledger et al. 1967 ). In several West African countries, game meat provides most of the small amount of animal protein consumed (Riney, I968); in 1966 Ghana produced nearly 28000 tons of meat from wild game (Crawford r968a). In I968, New Zealand, as a by-product of a drive to control red deer, exported about 3000 tons of venison (Bland, I 969). None the less, hunting is a poor way to exploit a population of wild herbivores. 
Game-cropping. Once the biology of a species of wild herbivores is sufficiently well understood, especially its ecological relationships and population dynamics, one can calculate how many animals one can kill each year to effect the maximum sustained yield of meat. It may take decades of careful study to accumulate sufficient knowledge, and once cropping has begun one must continually monitor the status of the stock and of the ecosystem of which it forms a part. The practice of selective slaughter, to maintain a high proportion of young animals with high conversion efficiency and to minimize natural wastage, and protective measures such as predator control, may cause the stock to deviate from the natural population to some extent. But interference with the animals should be kept to a minimum on the assumption that their natural behaviour patterns are those which will achieve optimal production.

Game-cropping of wild or half-wild reindeer was probably man's first step towards animal husbandry and is still practised in northern lands (Zeuner, 1963). A recent success story also relates to an animal living in a relatively simple ecosystem. The saiga-antelope, a small curious creature rescued from extinction in Siberia 40 ycars ago, now roams the steppe in vast herds (Bannikov, 196r). Its ability to migrate rapidly over great distances and its high fecundity enable it to avoid or recover from natural disasters. Carefully organized culling of the stock of some two million animals yields about 7000 tons of meat a year. In more complicated ecosystems, such as African savannah and woodland, a variety of herbivores with complcmentary feeding patterns must be exploited if greatest productivity and a proper balance are to be maintained (Darling, I960a; Lamprey, I963). Crawford (1968a) recommends a mixture of browsers such as giraffe and elephant, grazers such as buffalo and kob, and rooters such as warthog and bushpig. Ledger et al. ( 1967 ) calculate that the sustained yield (based on a $10 \%$ annual cull) from the nine most abundant large ungulates found in the Serengeti National Park amounts to 12765 tons live weight a year $\left(4^{\cdot} \cdot 7 \mathrm{~kg} / \mathrm{ha}\right)$. This probably exceeds substantially the yield from cattle pastured on such country, though it is only about $1 \%$ of the productivity that can be achieved on intensively-managed grassland in Britain (Joint Beef Production Committee, 1967).

Large animals have some advantage over small; they have a lower metabolic rate per $\mathrm{kg}$ body-weight so that, in principle, maintenance requirements are low and food conversion efficiency is high (Brody, I945), and locating and butchering them becomes simpler in some respects. In the protection of African national parks the hippopotamus and elephant have multiplied to such an extent that thousands have had to be killed; each hippopotamus is the equivalent of sixty sheep and each elephant the equivalent of eighty (Darling, I $960 b$ ).

Efficient and hygienic techniques for butchering, extraction and marketing of the meat and other products are needed and these may prove to be costly in remote, backward and mountainous or thickly-forested regions. Despite the many problems still to be solved, game-cropping promises to be an important method for increasing meat production at low cost in many parts of the world which are unsuited to intensive methods of raising stock. In fact, however, progress in this direction has been disappointingly slow, perhaps owing to lack of economic incentives. 
Game-farming and domestication. It seems strange that man has domesticated so few herbivorous mammals. In chronological order they comprise the reindeer, goat, sheep, cattle, and four related species, pig, elephant, horse, and two related species, camel, rabbit and llama (Zeuner, 1963). Once a settled mode of life had been adopted in Neolithic times it may have been more profitable and certainly less effort to adapt existing farm animals to changing needs rather than attempt to domesticate new species. This conservative attitude has not prevented a few experiments. The ancient Egyptians evidently tamed the hyaena, addax, gazelle and ibex, the Romans fattened dormice as a table delicacy (Zeuner, 1963) and, in the Victorian era, the enterprising Frank Buckland and fellow enthusiasts of the Acclimatization Society introduced various species such as the eland into Britain with a view to domestication (Burgess, 1967 ).

A number of animals have recently been put on the path to domestication or appear to be suitable (Bigalke \& Neitz, 1954; Bigalke, I964; Jewell, 1969). The African buffalo can be tamed and thrives under conditions which cattle cannot tolerate (Harthoorn, 1958; Jewell, 1969) but perhaps the most promising wild ruminant for meat production in dry tropical regions is the eland. It has catholic food habits, physiological and behavioural adaptations to hot and dry climates; it is docile and the quality of its carcass is cxcellent; it is about the size of a cow and seems a natural understudy. A herd of eland has been maintained for 72 years at Askaniya-Nova in the southern Ukraine; they are managed in the same way as cattle with little difficulty (Treus \& Kravchenko, I968). Young eland gained about $0.8 \mathrm{~kg} / \mathrm{d}$ when fattened and lactating cows produced $100-600 \mathrm{~kg}$ of milk rich in protein and fat per lactation. Other examples of the encouraging attempts by Soviet biologists to develop new species of domestic animals are the management of elk in a National Park in the northern Urals (Yazan \& Knorre, 1964), and the study of woodland and tundra reindeer and the digestive adaptations that occur when reindeer move from one habitat to the other (Sablina, 1960).

Recent work has shown not only the potential of new domestication but also the possibility of reversing the process; careful crossing of primitive breeds of European cattle has produced a fair replica of the extinct aurochs, Bos primigenius (Heck, I95 I).

With the exception of the pig and the rabbit, the domestic mammals we commonly eat are all ruminants. These ferment food in their forestomachs, as do some other animals such as the hippopotamus and the kangaroo. The success of the zebra and elephant in Africa suggests that animals fermenting food in their large intestine can compete successfully with ruminants, and hind-gut fermenters would be expected to have some advantages over ruminants when given rations rich in starch and protein. In the past, the horse has been exploited as the main source of meat and milk, especially by nomadic people who wished to combine transport and food supply in one animal. Another such animal unexpectedly staking a claim as a potential meat producer is the capybara, a South American rodent which weighs up to $70 \mathrm{~kg}$ and produces about ten young annually (Mondolfi, 1957).

There are many problems that must be overcome if wild game are to be successfully managed in the captive state. A thorough knowledge of their natural diet and 
habits is a first essential. Kettlitz (1962) summarizes experience gained in South Africa; blesbok, springbok and impala can be successfully managed but require quite large enclosures, the strength of fencing depending on the size of the enclosure and the training of the animals, whereas the territorial habits of steenbok make them unsuited to intensive management. Game may also act as a reservoir of disease (Urquhart \& Ross, 1962) which, although not necessarily deleterious to themselves, makes them unsuited to mixture with susceptible domestic animals; this fact has led to much opposition to the development of gamc-ranching. Nevertheless, on $5^{\circ}$ square miles of the Henderson Game Ranch in Rhodesia, studied by Dasmann (1963), the production of game meat has equalled the production of beef and has been much more profitable owing to the lower costs chargeable to the game animals.

\section{Red deer}

Finally, a homely example may be cited, lest it be thought that the production of game meat has no relevance in Britain. Our largest native ruminant is the red deer, a woodland animal now mainly confined to 2,000000 ha of exposed hill country in Scotland (Lowe, 1961). Since the utilization of this land by domestic species, mainly the sheep, is declining, an unusual meeting was convened in I 969 by the Highlands and Islands Development Board and the Rowett Research Institute to consider the husbandry of red deer for meat production.

The proceedings of this meeting have been published (Bannerman \& Blaxter, I 969). At present there are about I 80000 red deer in Scotland; they are remarkably free from disease. About one-sixth are killed each year yielding $\mathrm{r}_{5} 00$ tons of meat (about $0.7 \mathrm{~kg} / \mathrm{ha}$ ) which is mainly exported to West Germany. This sold for nearly $f_{500} 000$ in $1968-9$, since when market prices have doubled. While this provides a useful income to the sporting estates on which the deer are killed, the main objective is stalking rather than meat production. Little husbandry is practised; some estates are fenced and some provide a little supplementary food in winter. Scarcity of food in winter limits the deer to their present number and causes the death of about onethird of the calves.

There is plenty of room for improvement. Well-managed park deer weigh about $50 \%$ more than wild deer and achieve a much higher rate of reproduction, thanks to earlier puberty and less infertility and calf mortality, so that they can be cropped at a rate of one-third annually. Further improvements in productivity could no doubt be achieved by application of normal farm husbandry techniques-selective breeding and manipulation of the age and sex structure of the herd for example. The appetite and growth potential of the red deer are probably similar to those of North American deer (Wood \& Cowan, 1968), suggesting that intensive fattening may be a practical system.

The Nature Conservancy (1967) is making a thorough study of wild deer, and a small amount of laboratory research is in progress (Maloiy, Kay \& Goodall, 1968). While the possibility of farming deer on an extensive or intensive basis seems a promising one, the Rowett meeting concluded that more research was needed before economic husbandry could be practised (Bannerman \& Blaxter, 1969). A small 
deer farm has been started at Lincoln College, New Zealand; plans are afoot to found a larger unit soon in Scotland so that the expected and the unforeseen problems of deer management can be defined and studied.

\section{REFERENCES}

Bannerman, M. M. \& Blaxter, K. L. (editors) (1969). The Husbanding of Red Deer. Aberdeen: Aberdeen University Press.

Bannikov, A. G. ( $196 \mathrm{r}$ ). Terre Vie no. $\mathrm{x}, \mathrm{p} .77$.

Bertram, C. K. R. \& Bertram, G. C. L. (1968). Symp. zool. Soc. Lond. 21, 385 .

Bland, G. I. M. (1969). In The Husbanding of Red Deer p. I 3 [M. M. Bannerman and K. L. Blaxter, editors]. Aberdeen: Aberdeen University Press.

Bigalke, R. (1964). New Scient, 21, 14I.

Bigalke, R. \& Neitz, W. O. (I954). Fl S. Afr. vet. med. Ass. 25, 45.

Brody, S. (1945). Bioenergetics and Growth Ch. 13. New York: Reinhold Publishing Corp.

Burgess, G. H. O. (1967). The Curious World of Frank Buckland. London: John Baker.

Crawford, M. A. (1968a). Vet. Rec. 82, 305 .

Crawford, M. A. (I968b). Proc. Nutr. Soc. 27, 163.

Darling, F. F. (1960a). Wild Life in an African Territory. London: Oxford University Press.

Darling, F. F. (1960b). Scient. $A m .203$, no. 5, p. 123.

Dasmann, R. F. (1963). African Game Ranching. Oxford: Pergamon Press.

Eriksson, S. \& Schmekel, J. (1962). K. LantbrHögsk. Annlr 28, 175.

Fisher, J., Simon, N. \& Vincent, J. (1969). The Red Book: Wildlife in Danger. London: Collins.

Foot, J. Z. \& Romberg, B. (1965). Aust. F. agric. Res. 16, 429.

Garton, G. A. (1969). Lancet i, i2 27.

Golley, F. B. \& Buechner, H. K. (cditors) (1968). A Practical Guide to the Study of the Productivity of Large Herbivores. Oxford and Edinburgh: Blackwell Scientific Publications.

Harthoorn, A. M. (1958). Vet. Rec. 70, 939.

Harthoorn, A. M. (I968). In A Practical Guide to the Study of the Productivity of Large Herbivores p. II 7 [F. B. Golley and H. K. Buechner, editors]. Oxford and Edinburgh: Blackwell Scientific Publications.

Heck, H. (195ז). Oryx ז, II7.

Hustich, I. (1951). Acta geogr., Helsingf. r2, 40.

Jewell, P. A. (1969). In The Domestication and Exploitation of Plants and Animals p. ror [P. J. Ucko and G. W. Dimbleby, editors]. London: Gerald Duckworth \& Co.

Joint Beef Ptoduction Committee (1967). Beef Production Handbook no. I, p. 28. Reading: Bcef Recording Association.

Kettlitz, W. K. (1962). Fauna Flora, Pretoria 13, 19.

Lamprey, H. F. (1063). E. Afr. Wildl. F. 1, 63 .

Ledger, H. P. (I 968 ). Symp. zool. Soc. Lond. 21, 289.

Ledger, H. P., Sachs, R. \& Smith, N. S. (r967). Wld Rev. Anim. Prod. 3, 13.

Lowe, V. P. W. (196r). Terre Vie, no. I, p. 9.

Maloiy, G. M. O. (1965). Nutr. Abstr. Rev. 35, 903.

Maloiy, G. M. O., Kay, R. N. B. \& Goodall, E. D. (1968). Symp. zool. Soc. Lond. 2r, ror.

Maloiy, G. M. O., Kay, R. N. B., Goodall, E. D. \& Topps, J. H. (1970). Br. 7. Nutr. $24,843$.

Martin, A. C., Zim, H. S. \& Nelson, A. L. (1951). American Wildlife and Plants. New York: McGrawHill.

Mondolfi, E. (1957). Mamiferos de Venezuela : El Chigüire. El Farol, no. I68, p. $3^{8}$.

Nature Conservancy (1967). Red Deer Research in Scotland: Progress Report I. Edinburgh: The Nature Conservancy.

Nordfeldt, S., Cagell, W. \& Nordkvist, M. (196r). K. LantbrHögsk. St. LantbrFörsök, St. Husdjursförsök, Särtryck FörhMedd, no. $\mathbf{1}_{5} \mathbf{I}$.

Phillipson, A. T. (1967). Prac. Nutr. Soc. 26, т36.

Pirie, N. W. (I 968 ). In $A$ Practical Guide to the Study of the Productivity of Large Herbivores p. 228. [F. B. Golley and H. K. Buechner, editors]. Oxford and Edinburgh: Blackwell Scientific Publicam tions.

Price, R. \& Springfield, H. W. (1952). Proc. int. Grassld Congr. vi. Pennsylvania Vol. 1, p. 499.

Riney, T. (1968). Symp. zool. Soc. Lond. 21, 473.

Sablina, T. B. (1960). Trudy' Inst. Morf. Zhivot. 32, 215. (In Russian: see Biol. Abstr. 39, 378, 1962.)

Schmidt-Nielsen, K. (1964). Desert Animals. London: Oxford University Press. 
Talbot, L. M. (1963). Comparison of the Efficiency of Wild Animals and Domestic Livestock in Utilization of East African Rangelands. Publications of the International Union for Conservation of Nature and Natural Resources NS, no. I, p. 329 .

Talbot, L. M., Payne, W. J. A., Ledger, H. P., Verdcourt, L. D. \& Talbot, M. H. (r965). Tech. Commun. Commonw. Bur. Anim. Breed. Genet. no. 16.

Taylor, C. R. \& Lyman, C. P. (1967). Physiol. Zoöl. 40, 280.

Treus, V. \& Kravchenko, D. (1968). Symp. zool. Soc. Lond. 21, 395.

Urquhart, G. M. \& Ross, J. G. (1962). Vet, Rec. 74, 23 I.

Vesey-Fitzgerald, D. F. (1960). F. Mammal. 4I, r6I.

Wood, A. J. \& Cowan, I. McT. (I968). In A Practical Guide to the Study of the Productivity of Large Herbivores p. 106 [F. B. Golley and H. K. Buechner, editors]. Oxford and Edinburgh: Blackwell Scientific Publications.

Yazan, Y. \& Knorre, Y. (I964). Oryx 7, 301.

Zeuner, F. E. (1963). A History of Domesticated Animals. London: Hutchinson.

Ziswiler, V. (1967). Extinct and Vanishing Animals and ed. London: Longmans, Green \& Co.

\title{
The future pattern of food consumption and marketing
}

\author{
By P. J. Baron, The University, Newcastle upon Tyne
}

Undoubtedly, population growth will in the future lead to an increase in the general market size, although this factor will be of much greater importance to developing than to the developed economies. It is, however, the individual's requirements and pattern of food consumption which is of more interest to a study of future markets for individual products such as those derived from animals.

It is commonly accepted that as real incomes rise a declining proportion is spent on food. In the UK, for example, it has, in the decade between 1958 and r968, dropped from $26 \%$ to $21 \%$ (Central Statistical Office, I969). At the same time it is accepted that as real incomes rise an increasing proportion of food expenditure will be switched to foods with a high protein: energy ratio such as those derived from animals rather than plants. Although there is evidence of such increases, the broad food categories used prevents detailed comment.

The most useful data for detailed observation of consumer behaviour (see annual reports of the National Food Survey Committee, Ministry of Agriculture, Fisheries and Food, I967, I968, I969) relate to household consumption and exclude meals eaten outside the home. Although canteen, restaurant and institutional eating is increasing (Department of Employment and Productivity, I969), household consumption is by far the larger proportion and can be used to demonstrate fundamental relationships. Table I shows figures derived from these surveys. The breakdown is fairly broad but clearly illustrates the importance of poultry, pork and processed meats as contributors to growth in per caput meat consumption. They are, moreover, realizing an increasing share of total meat sales while the more traditional meats are unaltered or even declining. For dairy products, cheese shows an increasing importance while full price milk and butter remain comparatively stable. Eggs show but slight increase. 